\title{
ОСОБЛИВОСТІ ЗМІН АНТИОКСИДАНТНОЇ СИСТЕМИ В ДИНАМІЦІ ІММОБІЛІЗАЦІЙНОГО СТРЕСУ НА ТЛІ
} ГІПОТИРЕОЗУ

\begin{abstract}
Резюме. У патогенезі багатьох патологічних станів важливе місце посідають порушення антиоксидантної системи. При відсутності належного контролю за активністю процесів вільнорадикального окиснення розвивається ряд патологічних станів, що супроводжуються виникненням деструктивних, запальних та імунних реакцій. Ряд дослідників встановив захисну дію йодовмісних тиреоїдних гормонів при стресі, що реалізуються в результаті їх взаємодії із клітинним геномом, який призводить до стимуляції локальних стрес-лімітуючих систем.

Мета дослідження - вивчити особливості змін показників ферментної і несрерментної ланок функціонування антиоксидантної системи за умов іммобілізаційного стресу на тлі зниження рівня йодовмісних гормонів щитоподібної залози.

Матеріали і методи. Гіпотиреоз моделювали щоденним введенням per os тиреостатика “Мерказоліл” (“Здоров'я”, Україна) у дозі 25 мг/кг протягом 21-ї доби. Гострий іммобілізаційний стрес моделювали шляхом прив'язування дослідних щурів у положенні на спині за 4 кінцівки без обмеження рухомості голови на 3 год. Для дослідження концентрації йодовмісних гормонів щитоподібної залози використовували імуноферментні методи, показників антиоксидантної системи - спектрофоотометричні методи.

Результати досліджень та їх обговорення. Досліджено вплив іммобілізаційного стресу в щурів із попередньо змодельованим гіпотиреозом на показники антиоксидантної системи крові. На стадії тривоги розвитку стрес-реакції в евтиреоїдних тварин встановлено незначне пригнічення антиоксидного захисту, що проявляється зниженням активності основних антиокситдантів першої лінії - каталази і супероксиддисмутази, зменшення концентрації церулоплазміну та пригнічення глутатіонової ланки антиоксидантної системи. На стадії резистентності відбувається стабілізація, а у ряді випадків і підвищення показників антиоксидантної системи відносно тварин без патології. Однак при тривалому стресі (стадія виснаження) антиоксидантний потенціал крові знову достовірно знижується, що свідчить про виснаження захисного антиоксидантного резерву. У тварин із гіпотиреозом на усіх стадіях розвитку стрес-реакції має місце достовірне пригнічення антиоксидантної здатності крові як стосовно тварин без змодельованої патології, так і евтиреоїдних тварин з іммобілізаційним стресом.

Висновки. На тлі гіпотиреозу спостерігається більш інтенсивне, ніж в евтиреоїдних тварин, пригнічення антиоксидантної здатності крові.
\end{abstract}

Ключові слова: стрес; гіпотиреоз; антиоксидантна система.

ВСтУп Щитоподібна залоза є ключовим органом ендокринної системи і важливою ланкою регуляції обмінних процесів в організмі людини. Усі фрізіологічні стани людини реагують на рівень ії гормональної активності. Знижена продукція тиреоїдних гормонів впливає на фрункцію і стан багатьох органів і систем [11].

Стрес-система - складний регуляторний комплекс, що допомагає координувати гомеостаз у звичайних умовах і відіграє ключову роль в активації й координації усіх змін в організмі, що становлять адаптивну реакцію на стресори. Порушення регуляції стрес-системи значною мірою пов'язане з недостатністю фрункції стрес-лімітуючих систем, призводить не тільки до порушення реакції організму на стресори, але й до виникнення або схильності до різних захворювань [4].

Дію стрес-системи на рівні органів й тканин обмежують системи локальної регуляції - локальні стрес-лімітуючі системи. Вони пригнічують вивільнення катехоламінів із нервових закінчень і надниркової залози й дію цих моноамінів на постсинаптичному рівні, зменшуючи тим самим активацію вільнорадикального окиснення (ВРО) і обмежуючи надмірну стрес-реакцію і її ушкоджувальну дію на органи й тканини [2].

Важливу роль в обмеженні активації ВРО й ушкодженні при стресі відіграють антиоксидантні системи, що також належать до локальних стрес-лімітуючих систем органів і тканин. Відомо, що система антиоксидантного захисту, що протистоїть шкідливому ефекту вільних радикалів, які безперервно утворюються в організмі людини, представлена несрерментним і фрерментним компонентами $[1,12,13]$. Пригнічення антиоксидантного захисту закономірно призводить до інтенсифрікації вільнорадикальних процесів, у т.ч. пероксидного окис- нення ліпідів (ПОЛ), що відіграє ключову роль у патогенезі багатьох патологічних процесів [3, 14]. 3 іншого боку, встановлено, що малі дози йодовмісних тиреоїдних гормонів (ЙТГ) лімітують інтенсивність процесів ліпопероксидації за рахунок їх стимулювального впливу на активність ряду компонентів антиоксидантної системи [12]. Однак вплив гіпофрункції щитоподібної залози на активність зазначених антиоксидантних фрерментів в умовах стресу вивчено недостатньо.

Метою дослідження було вивчити особливості змін показників ферментної і неферментної ланок антиоксидантної системи за умов іммобілізаційного стресу, що реалізується на тлі гіпотиреозу.

МАТЕРІАЛИ І МЕТОДИ ДЛЯ вИвчення особливостей перебігу стрес-реакції на тлі гіпотиреозу використовували білих щурів-самців лінії Вістар, яких утримували на стандартному раціоні віварію при вільному доступі до води відповідно до вимог Правил проведення робіт з використанням експериментальних тварин та Європейської конвенції про захист хребетних тварин, що використовуються для дослідних та інших наукових цілей (Страсбург, 1986) $[10,19]$. В кожну експериментальну групу методом випадкової вибірки було включено по 10 тварин масою $(210 \pm 20)$ г. Усього в дослідженні було використано 84 щури, однак унаслідок загибелі упродовж експерименту на момент евтаназії було 80 особин.

Гіпотиреоз моделювали щоденним введенням per os за допомогою зонда фрармакопейного тиреостатика "Мерказоліл" (“Здоров'я”, Україна) у дозі 25 мг/кг протягом 21-ї доби [15]. Повноту досягнення гіпотиреозу контролювали вимірюванням концентрації трийодтироніну і тироксину в сироватці крові, а також за динамікою маси тварин та їх рухової активності. 
Вплив гіпотиреозу на перебіг іммобілізаційного стресу вивчали на моделі іммобілізаційного стресу [2]. Гострий іммобілізаційний стрес (ГІС) моделювали шляхом прив'язування піддослідних щурів у положенні на спині за 4 кінцівки без обмеження рухомості голови на 3 год. Дослідження проводили через 2 (стадія тривоги) та 48 (стадія резистентності) год після завершення дії стресорного фактора. Хронічний іммобілізаційний стрес (XIC), що є аналогом стадії виснаження, моделювали тим же методом, який повторювали протягом 5 діб. Дослідження проводили через 2 год після останнього моделювання [2].

Експериментальних тварин поділили на 8 груп:

- інтактні тварини, яким перорально вводили дистильовану воду протягом 21-ї доби;

- щури, яким моделювали гіпотиреоз шляхом перорального уведення мерказолілу в дозі 25 мг/кг протягом 21-ї доби;

- тварини, яким моделювали гострий іммобілізаційний стрес і проводили евтаназію на стадії тривоги (2 год);

- щури, яким моделювали гострий іммобілізаційний стрес і проводили евтаназію на стадії резистентності (48 год);

- тварини, яким моделювали гострий іммобілізаційний стрес на тлі попередньо змодельованого гіпотиреозу (стадія тривоги);

- щури, яким моделювали гострий іммолізіційний стрес на тлі попередньо змодельованого гіпотиреозу (стадія резистентності);

- тварини, яким моделювали хронічний іммобілізаційний стрес;

- щури, яким моделювали хронічний іммобілізаційний стрес на тлі попередньо змодельованого гіпотиреозу.

Для дослідження використовували цільну кров та плазму крові. Тварин декапітували під тіопенталовим наркозом через 2 та 48 год від моменту завершення одноразової іммобілізації та через 2 год від моменту завершення моделювання хронічного іммобілізаційного стресу.

Вміст загального тироксину $\left(\mathrm{T}_{4}\right)$ і загального трийодтироніну $\left(\mathrm{T}_{3}\right)$ в сироватці визначали імунофрлуоресцентним методом із використанням стандартних тест-наборів "Immulite 1000". Концентрацію гормонів виражали в пмоль/л.

Стан антиоксидантної системи оцінювали за активністю супероксиддисмутази (СОД) за методом [16] у модисрікації [9] і каталази (КТ) [5] та концентрації відновленого глутатіону [18] у цільній крові, церулоплазміну (ЦП) за методом [7] у плазмі крові та активності глутатіонпероксидази і глутатіонредуктази [6] в гомогенаті печінки. Загальну антиоксидну активність плазми (ЗААП) крові визначали за її здатністю гальмувати утворення продуктів ліпопероксидації у гомогенаті мозку щурів $[1,17]$

Статистичну обробку цифрових даних здійснювали за допомогою програмного забезпечення Excel та STATISTICA 3 використанням параметричних і непараметричних методів оцінки отриманих даних. Для усіх показників розраховували значення середньої арифметичної вибірки (М), її дисперсії і помилки середньої (m). Достовірність різниці значень між незалежними кількісними величинами визначали при нормальному розподілі за t-критерієм Стьюдента, в інших випадках - за допомогою U-критерію Манна-Уїтні (достовірним вважали відмінності при р<0,05) [8].
РЕЗУЛЬТАТИ ДОСЛІДЖЕНЬ ТА ЇХ ОБГОВОРЕННЯ 3 метою оцінки функціонального стану щитоподібної залози у тварин, яким моделювали гіпотиреоз, визначали концентрацію тиреоїдних гормонів у крові. Концентрація $\mathrm{T}_{3}$ у здорових щурів склала $(5,96 \pm 0,22)$ пмоль/л, а у тварин, яким вводили мерказоліл, показник був знижений у 2,7 раза і становив $(2,19 \pm 0,21)$ пкмоль/л. Концентрація $\mathrm{T}_{4}$ в інтактних тварин становила $(10,16 \pm 0,69)$ пкмоль/л, а після уведення мерказолілу зменшилась у 2,4 раза від показника інтактних щурів і склала $(4,27 \pm 0,28)$ пкмоль/л. Ми спостерігали також суб'єктивні ознаки гіпотиреозу зменшення рухливості, інтенсивніше, ніж в інтактних тварин зростала маса тіла, змінювалась шерсть. Це вказує на розвиток у щурів явищ гіпотиреозу внаслідок уведення мерказолілу в дозі 25 мг/кг протягом 21-ї доби.

У тварин із гіпотиреозом супероксиддисмутазна активність крові була достовірно нижчою, ніж у щурів без змодельованої автології і склала 68,7 \% від їх рівня. В евтиреоїдних тварин, яким моделювали іммобілізаційний стрес, спостерігали фразові зміни активності СОД. Зокрема, на стадії тривоги ензимна активність зростала, порівняно з тваринами без патології, до 113,8 \%. На стадії резистентності було подальше зростання супероксиддисмутазної активності й вона досягла рівня 127,3 \% від норми. Однак на стадії виснаження, після моделювання стресу протягом 5 діб, активність СОД знижувалась до 88 \% від рівня тварин без змодельованої патології.

Моделювання стресу на тлі гіпотиреозу свідчило про зниження супероксиддисмутазної активності на усіх стадіях патологічного процесу. Зокрема, на стадії тривоги показник склав 80,4 \% від рівня тварин без змодельованої патології, що також на 40,5% менше від евтиреоїдних щурів на відповідній стадії. На стадії резистентності показник дещо зріс, що однак склало лише 71,8 \% від рівня евтиреоїдних тварин. Моделювання хронічного стресу на тлі гіпотиреозу призвело до найзначнішого зниження активності СОД - показник склав 67,9 \% від норми, а це 77,1 \% від аналогічного показника евтиреоїдних щурів на цій стадії стресу.

Каталазна активність крові також зазнавала змін. Моделювання гіпотиреозу призвело до достовірного зниження ензимної активності, що склало 63,9 \% від норми. Моделювання іммобілізаційного стресу в евтиреоїдних тварин на стадіях тривоги супроводжувалось незначним зниженням досліджуваних показників, яке однак було не достовірним. Більш значне зменшення каталазної активності мало місце на стадії виснаження - показник склав 60,5 \% від рівня тварин без змодельованої патології.

Дефіцит йодовмісних гормонів щитоподібної залози призводить до більш виражених змін активності каталази. Зокрема, уже на стадії тривоги показник склав 49,3 \% від норми, що достовірно менше також від відповідного показника в евтиреоїдних тварин. На стадії резистентності відбувається суттєве покращання каталазної активності, порівняно з попереднім періодом, - показник склав 90,3 \% від рівня щурів без змодельованої патології і майже не відрізнявся від відповідного показника евтиреоїдних тварин. Однак на стадії виснаження каталазна активність знову різко знизилась - до 38,2 \% від рівня щурів без патології, що також достовірно нижче від показника аналогічної групи евтиреоїдних тварин.

Концентрація основного антиоксиданта плазми крові - церулоплазміну змінювалась менш виражено, ніж ак- 
тивність ферментів I лінії антиоксидантного захисту, однак певні зміни також відбувались. У тварин із гіпотиреозом показник склав 93 \% від норми. В евтиреоїдних щурів, яким моделювали іммобілізаційний стрес, концентрація церулоплазміну змінювалась залежно від стадії процесу. Зокрема, на стадії тривоги ми зафріксували достовірне зниження показника ЦП, що склав 82,4 \% від рівня тварин без патології. Однак до подальшої стадії резистентності відбулось повне відновлення концентрації ЦП. Проте вже у наступній стадії - виснаження мало місце чергове суттєве зменшення вмісту ЦП, який склав 67,4 \% від рівня тварин, яким патологічні процеси не моделювали. За умови дефіциту йодовмісних гормонів щитоподібної залози тенденція була дещо іншою - концентрація ЦП знижувалась на усіх стадіях іммобілізаційного стресу. На стадії тривоги показник склав 55,3 \% від рівня щурів без патології, достовірно відрізняючись також від аналогічного показника евтиреоїдних тварин. На стадії тривоги, на відміну від евтиреоїдних щурів, відновлення концентрації ЦП не відбулося, вона становила лише 68 \% від норми і також була нижчою, ніж у тварин із нормальним вмістом тиреоїдних гормонів. Подальше зниження відбувалось при тривалому моделюванні стресу - показник склав 58,2 \% від норми, що на 9,2 \% менше, ніж в евтиреоїдних щурів.

Аналогічна тенденція мала місце і при дослідженні ЗААП. Спостерігали достовірне зменшення показника на усіх стадіях іммобілізаційного стресу в евтиреоїдних тварин та ще більш виражене його зниження у тварин із дефріцитом йодовмісних гормонів щитоподібної залози. Причому, максимально низькі показники в обох групах тварин ми відмітили за умов хронічного іммобілізаційного стресу. В евтиреоїдних щурів цей показник склав 56,7 \% від норми, а у тварин із гіпотиреозом - 42,7 \% (табл. 1).

Глутатіон є центральним компонентом антиоксидантних систем майже в усіх клітинах і органах. Його антиоксидантна дія пов'язана з перенесенням сульсргідрильних груп. За участі глутатіонпероксидази він віддає свої протони, перетворюючись на дисульсрід, завдяки чому відбувається знешкодження продуктів ліпопероксидації. Глутатіонредуктаза перетворює глутатіон у відновлену форму. Активність глутатіонпероксидази в організмі багато в чому визначає динаміку патологічних процесів. При зниженні активності глутатіонпероксидази порушується захист клітин від екозо- та ендогенних токсикантів.

У наших дослідженнях основні показники глутатіонової ланки антиоксидантної системи знижувались (табл. 2). Зокрема, у тварин із гіпотиреозом глутатіонпероксидазна активність крові була меншою, ніж у щурів без патології на 24,6 \%. За моделювання ГІС евтиреоїдним тваринами ми спостерігали залежність ензимної активності від стадії патологічного процесу. На стадії тривоги ГП склала 73,5 \% від рівня щурів без патології, однак на стадії резистентності показник підвищився до 92,1%. Тривале моделювання стресової ситуації призвело до повторного достовірного зниження глутатіонпероксидазної активності - показник склав 76,3 \% від норми.

Моделювання ГІС тваринам із гіпотиреозом супроводжувалось біль вираженими змінами активності ГП. Уже на стадії тривоги показник був на 42,3 \% меншим, ніж у щурів без змодельованої патології, і склав 95,6 \% від рівня евтиреоїдних щурів на відповідній стадії стресу. На

Таблиця 1. Динаміка показників антиоксидантної активності крові щурів з іммобілізаційним стресом на тлі гіпотиреозу $(\mathrm{M} \pm \mathrm{m})$

\begin{tabular}{|c|c|c|c|c|c|}
\hline & $\begin{array}{c}\text { Показник/ } \\
\text { група тварин }\end{array}$ & $\begin{array}{l}\text { СОД, кров } \\
\text { (ум. од./мл) }\end{array}$ & $\begin{array}{c}\text { Каталаза, кров } \\
\text { (ум. од./мл) }\end{array}$ & ЦП (мг/л) & ЗААП (\%) \\
\hline Без патології ( & $=12)$ & $4,76 \pm 0,4$ & $0,835 \pm 0,025$ & $273,8 \pm 8,7$ & $49,56 \pm 0,48$ \\
\hline Гіпотиреоз $(\mathrm{n}=$ & & $3,27 \pm 0,02^{*}$ & $0,534 \pm 0,03^{*}$ & $254,9 \pm 11,3^{*}$ & $38,22 \pm 0,8^{*}$ \\
\hline & ГІС (стадія тривоги) (n=10) & $5,38 \pm 0,06^{*}$ & $0,782 \pm 0,053^{\star}$ & $225,7 \pm 13,3^{*}$ & $31,17 \pm 0,34^{*}$ \\
\hline ІМмобІлІза- & ГІС (стадія резистентності) $(\mathrm{n}=10)$ & $6,06 \pm 0,02^{*}$ & $0,821 \pm 0,11$ & $280,5 \pm 11,7$ & $42,22 \pm 0,27$ \\
\hline & XIC (стадія виснаження) (n=9) & $4,19 \pm 0,03^{*}$ & $0,505 \pm 0,109 *$ & $184,23 \pm 6,7^{*}$ & $28,11 \pm 0,14^{*}$ \\
\hline & ГІС (стадія тривоги) (n=10) & $3,83 \pm 0,05^{\star \#}$ & $0,412 \pm 0,104^{\star \#}$ & $151,5 \pm 9,8^{\star \#}$ & $23,21 \pm 0,18^{\text {*\# }}$ \\
\hline & ГІС (стадія резистентності) $(\mathrm{n}=10)$ & $4,35 \pm 0,03^{\#}$ & $0,654 \pm 0,047^{\text {*\# }}$ & $187,4 \pm 10,3^{\text {*\# }}$ & $28,43 \pm 0,23^{\text {*\# }}$ \\
\hline & XIC (стадія виснаження) (n=7) & $3,23 \pm 0.04^{\star \#}$ & $0,319 \pm 0,034^{\star \#}$ & $159,1 \pm 13,5^{\star \#}$ & $21,14 \pm 0,1^{\text {*\# }}$ \\
\hline
\end{tabular}

Примітки: тут і в наступній таблиці:

$1)^{\star}$ - зміни показників евтиреоїдних і гіпотиреоїдних тварин із гострим і хронічним стресом достовірні відносно інтактних (р<0,05);

2) - зміни показників гіпотиреоїдних тварин із гострим і хронічним стресом достовірні відносно показників евтиреоїдних на відповідні доби дослідження ( $p<0,05)$.

Таблиця 2. Динаміка показників глутатіонової ланки антиоксидантної системи щурів 3 іммобілізаційним стресом на тлі гіпотиреозу (M士m)

\begin{tabular}{|c|c|c|c|c|}
\hline \multicolumn{2}{|c|}{\begin{tabular}{|c|} 
Показник/ \\
група тварин
\end{tabular}} & $\begin{array}{l}\mathrm{BГ,} \mathrm{кров} \\
\text { (мг/л) }\end{array}$ & $\begin{array}{c}\text { ГП, печінка } \\
\text { (ммоль/хв×кг) }\end{array}$ & $\begin{array}{c}\text { ГР, печінка } \\
\text { (ммоль/хв×кг) }\end{array}$ \\
\hline \multicolumn{2}{|c|}{ Без патології (n=12) } & $4,21 \pm 0,24$ & $0,279 \pm 0,014$ & $72,74 \pm 2,32$ \\
\hline \multicolumn{2}{|c|}{ Гіпотиреоз (n=12) } & $3,28 \pm 0,09 *$ & $0,224 \pm 0,011^{*}$ & $65,21 \pm 1,71^{*}$ \\
\hline \multirow{3}{*}{$\begin{array}{l}\text { Іммобіліза- } \\
\text { ційний стрес }\end{array}$} & ГІС (стадія тривоги) (n=10) & $4,06 \pm 0,22$ & $0,205 \pm 0,008^{*}$ & $61,22 \pm 1,34^{*}$ \\
\hline & ГІС (стадія резистентності) (n=10) & $4,99 \pm 0,15^{\star}$ & $0,257 \pm 0,011$ & $73,14 \pm 2,11$ \\
\hline & XIC (стадія виснаження) (n=9) & $4,19 \pm 0,23$ & $0,213 \pm 0,014^{*}$ & $57,36 \pm 2,21^{*}$ \\
\hline \multirow{3}{*}{$\begin{array}{c}\text { ГТ+ } \\
\text { іммобіліза- } \\
\text { ційний стрес }\end{array}$} & ГІС (стадія тривоги) (n=10) & $3,54 \pm 0,24^{\star \#}$ & $0,196 \pm 0,009 * \#$ & $50,67 \pm 1,71^{\star \#}$ \\
\hline & ГІС (стадія резистентності) $(\mathrm{n}=10)$ & $3,78 \pm 0,36^{\#}$ & $0,214 \pm 0,009 * \#$ & $55,48 \pm 1,54^{\star \#}$ \\
\hline & XIC (стадія виснаження) (n=7) & $3,04 \pm 0,30 * \#$ & $0,174 \pm 0,008^{* \#}$ & $47,22 \pm 1,32^{\star \#}$ \\
\hline
\end{tabular}


стадії резистентності відбулося незначне зростання ензимної активності, порівняно з попереднім терміном спостереження, однак показник був достовірно меншим від норми, а також евтиреоїдних щурів на цій же стадії. Найвираженіше зниження активності ГП у цій групі тварин ми відмітили на стадії виснаження - показник склав 62,4 \% від рівня щурів без патології і був на 29,9 \% меншим, ніж відповідний показник евтиреоїдних тварин.

Динаміка активності ГР, фрерменту який забезпечує відновлення глутатіону, за спрямуванням була аналогічною до глутатіонпероксидазної активності. Зокрема, у тварин із ГІС на стадії тривоги показник склав 84,1 \% від норми, що забезпечило достатній рівень відновлення глутатіону, показник якого достовірно не відрізнявся від норми. На стадії резистентності глутатіонредуктазна активність нормалізувалась, а показник ВГ навіть перевищував норму на 11,5 \%. На стадії виснаження активність ГР знову знизилась до 78,9 \% від рівня тварин без патології, а концентрація ВГ, хоч і знизилась, порівняно з попередньою стадією, однак достовірно не відрізнялась від норми.

Моделювання стресу в тварин із гіпотиреозом призвело до більш виражених змін. Глутатіонредуктазна активність на стадії тривоги склала 69,7 \% від норми і

\section{СПИСОК ЛІТЕРАТУРИ}

1. Арутюнян А. В. Методы оценки свободнорадикального окисления и антиоксидантной системы организма : метод. рекоменд. / А. В. Арутюнян, Е. Е. Дубинина, Н. Н. Зыбина. - СПб. : ИКФ "Фолиант", 2000. - 104 с.

2. Бондаренко С. Н. Влияние различных методик стрессирования и адаптации на поведенческие и соматические показатели у крыс / С. Н. Бондаренко, Н. А. Бондаренко, Е. Б. Манухина // Бюллетень экспериментальной биологии и медицины. - 1999. - T. 128, № 8. - C. 157-160.

3. Верба Р. В. Стан вільнорадикального окиснення та антиоксидантної системи за умов експериментального гострого перитоніту на тлі гіпотиреозу / Р. В. Верба, І.М.Кліщ // Медична та клінічна хімія. - 2016. - Т. 18, № 4. - С. 23-28.

4. Данилкина О. П. Физиология стресса животных [Електронний ресурс] / О. П. Данилкина ; Краснояр. гос. аграр. ун-т. Красноярск, 2016. - 32 с.

5. Грищук С. В. Определение активности каталазы цельной крови как возможный метод доклинической оценки риска легочных заболеваний у свиней / С. И. Грищук, В. И. Дудин // Проблемы биологии продуктивных животных. - 2008. - № 2. - С. 65-72.

6. Круглікова Г. О. Глутатіонпероксидазна та глутатіонредуктазна активність печінки після введення селеніту натрію / Г. О. Круглікова, І. М. Штурман / / Український біохімічний журнал. - 1976. - T. 48, № 2. - С. 223-228.

7. Колб В. Г. Справочник по клинической химии / В. Г. Колб, В. С. Камышников. - Минск, 1982. - 311 с.

8. Лапач С. Н. Статистические методы в медико-биологических исследованиях с использованием Excel / С. Н. Лапач, А. В. Чубенко, П. Н. Бабич. - К. : Морион, 2000. - 320 с.

9. Макаревич О. П. Активность супероксиддисмутазы крови в острый период различных заболеваний / О. П. Макаревич, П. П. Голиков // Лаб. дело - 1983. - № 6. - С. 24-27. була на 20,8 \% меншою, ніж в евтиреоїдних щурів на відповідній стадії стресу. Наслідком цього стало достовірне зниження концентрації ВГ (84,1 \% від норми), що на 14,7 \% менше, ніж у тварин із нормальною фрункцією щитоподібної залози. На стадії резистентності глутатіонредуктазна активність дещо зросла, однак на стадії виснаження спостерігали подальше зменшення досліджуваних показників. Глутатіонредуктазна активність крові склала 64,9 \% від рівня тварин без патології, що на 25,1 \% менше від показника евтиреоїдних щурів на цій стадії, а концентрація ВГ склала 72,2 \% від норми, що також достовірно менше, ніж в евтиреоїдних тварин.

Отже, за умов дефріциту йодовмісних гормонів щитоподібної залози фрункціонування глутатіонової ланки антиоксидантного захисту значно знижується, що може спричинити надмірне утворення продуктів ліпопероксидації та ушкодження клітинних мембран.

ВИСНОВКИ 1. Стан антиоксидного захисту за умов моделювання іммобілізаційного стресу залежить від фрази його перебігу.

2. У щурів із десріцитом йодовмісних гормонів щитоподібної залози має місце пригнічення антиоксидного захисту на усіх стадіях іммобілізаційного стресу.

10. Науково-практичні рекомендації з утримання лабораторних тварин та роботи з ними / Ю. М. Кожем'якін, О. С. Хромов, М. А. Філоненко, Г. А. Сайфетдінова. - К. : Авіцена, 2002. - 156 с.

11. Паньків В. І. Синдром гіпотиреозу / В. І. Паньків // Международный эндокринологический журнал. - 2012. - № 5 (45). - С. 136-148.

12. Про- и антиоксидантная система у больных гипотирозом и ее изменения под влиянием препаратов липоевой кислоты / А. С. Аметов, Е. С. Белоножкина, И. И. Павлюченко, А. А. Басов // Пробл. эндокринологии. - 2007. - Т. 53, № 2. - С. 49-54.

13. Пустовалова Л. М. Практикум по биохимии / Л. М. Пустоварова. - Ростов н/Д : "Феникс", 2009. - 544 с.

14. Резуненко Ю. К. Активність антиоксидантної системи в організмі щурів за умов тривалого впливу поліолів на основі гліцеролу, етилен- і пропіленгліколю / Ю. К. Резуненко, В. О. Прокопов // Проблеми екології та медицини. - 2011. T. 15, № 5/6. - С. 53-56.

15. Ром-Бугославська О. С. Доклінічне вивчення тиреостатичних та тиреоїд-стимулюючих засобів / О. С. Ром-Бугославська, Т. С. Божко, І. В. Комарова // Доклінічні дослідження лікарських засобів : метод. рекоменд. - К., 2001. - С. 409-420.

16. Чевари С. Роль супероксидредуктазы в окислительных процессах клетки и метод определения ее в биологическом материале / С. Чевари, И. Чаба, Й. Секей // Лаб. дело. - 1985. № 11. - C. 678-681.

17. Assay using brain homogenate for measuring the antioxidant activity of biological fluids / J. Stock, J. M. Gutteridge, R. J. Sharp, I. L. Dormandy // Clin. Sci. and Mol. Med. -1974. -47, No. 3. - P. 215-222.

18. Ellman G. L. Tissue sulfhydryl groups / G. L. Ellman // Arch. Biochem. Biophys. - 1959. - Vol. 82, No. 1. - P. 70-77.

19. European convention for the protection of vertebrate animals used for experimental and other scientific purposes. - Council of Europe. Strasbourg. - 1986. - No. 123. - P. 52. 

OF HYPOTHYROIDISM

Summary. In the pathogenesis of many pathological conditions, an important place is occupied by violations of the antioxidant system. In the absence of proper control over the activity of free radical oxidation processes, a number of pathological conditions develop, accompanied by the occurrence of destructive, inflammatory and immune reactions. A number of researchers have established the protective effect of iodine-containing thyroid hormones during stress, which is realized as a result of their interaction with the cellular genome, which leads to the stimulation of local stress-limiting systems.

The aim of the study - to establish the features of the functioning of the antioxidant system in conditions of immobilization stress against the background of a decrease in the level of iodine-containing thyroid hormones.

Materials and Methods. Hypothyroidism was modeled by daily per os injection of mercazole thyreostatics (Health, Ukraine) at a dose of $25 \mathrm{mg} / \mathrm{kg}$ for 21 days. Acute immobilization stress was modeled by tying experimental rats in a supine position in 4 limbs without limiting the mobility of the head for 3 hours. To study the concentration of iodine-containing thyroid hormones, enzyme immunoassay methods were used, and indicators of the antioxidant system were spectrophotometric methods.

Results and Discussion. The effect of immobilization stress in rats with pre-modeled hypothyroidism on the indicators of the antioxidant system of the blood was studied. At the stage of anxiety of the development of a stress reaction in euthyroids, insignificant inhibition of antioxidant protection was observed, manifested by a decrease in the activity of the main antioxidants of the first line - catalase and superoxide dismutase, a decrease in the concentration of ceruloplasmin and inhibition of the glutathione link of the antioxidant system. At the stage of resistance, stabilization occurs, and in some cases an increase in the performance of the antioxidant system relative to animals without pathology. However, with prolonged stress (exhaustion stage), the antioxidant potential of the blood again decreases significantly, which indicates the depletion of the protective antioxidant reserve. In animals with hypothyroidism at all stages of the development of the stress reaction, there is a significant suppression of the antioxidant ability of the blood in both animals without modeled pathology and euthyroid animals with immobilization stress.

Conclusion. Against hypothyroidism, there is more intense inhibition of antioxidant ability of blood than in euthyroid animals.

Key words: stress; hypothyroidism; antioxidant system.

(с). Е. Любович, И. Н. Клищ

ГвУз “Тернопольский государственный медицинский университет имени И. Я. Горбачевского”

\section{ОСОБЕННОСТИ ИЗМЕНЕНИЙ АНТИОКСИДАНТНОЙ СИСТЕМЫ В ДИНАМИКЕ ИММОБИЛИЗАЦИОННОГО СТРЕССА НА} ФОНЕ ГИПОТИРЕОЗА

Резюме. В патогенезе многих патологических состояний важное место занимают нарушения антиоксидантной системы. При отсутствии надлежащего контроля за активностью процессов свободнорадикального окисления развивается ряд патологических состояний, сопровождающихся возникновением деструктивных, воспалительных и иммунных реакций. Ряд исследователей установил защитное действие йодсодержащих тиреоидных гормонов при стрессе, реализуемых в результате их взаимодействия с клеточным геномом, что приводит к стимуляции локальных стресс-лимитирующих систем.

Цель исследования - изучить особенности изменений показателей ферментного и недеерментного звеньев антиоксидантной системы в условиях иммобилизационного стресса на фоне снижения уровня йодсодержащих гормонов щитовидной железы. Материалы и методы. Гипотиреоз моделировали ежедневным введением per os тиреостатика "Мерказолил" ("Здоровье", Украина) в дозе 25 мг/кг в течение 21-х суток. Острый иммобилизационный стресс моделировали путем привязывания опытных крыс в положении на спине за 4 конечности без ограничения подвижности головы продолжительностью 3 ч. Для исследования концентрации йодсодержащих гормонов щитовидной железы использовали иммуноферментные методы, показателей антиоксидантной системы - спектрофотометрические методы.

Результаты исследований и их обсуждение. Исследовано влияние иммобилизационного стресса у крыс с предварительно смоделированным гипотиреозом на показатели антиоксидантной системы крови. На стадии тревоги развития стресс-реакции в эутиреоидных животных установлено незначительное угнетение антиоксидной защиты, проявляющейся снижением активности основных антиоксидантов первой линии - каталазы и супероксиддисмутазы, уменьшением концентрации церулоплазмина и угнетением глутатионового звена антиоксидантной системы. На стадии резистентности происходит стабилизация, а в ряде случаев и повышение показателей антиоксидантной системы относительно животных без патологии. Однако при длительном стрессе (стадия истощения) антиоксидантный потенциал крови снова достоверно снижается, что свидетельствует об истощении защитного антиоксидантного резерва. У животных с гипотиреозом на всех стадиях развития стресс-реакции имеет место достоверное подавление антиоксидантной способности крови как у животных без смоделированной патологии, так и эутиреоидных животных с иммобилизационным стрессом.

Выводы. На фоне гипотиреоза наблюдается более интенсивное, чем в эутиреоидных животных, угнетение антиоксидантной способности крови.

Ключевые слова: стресс; гипотиреоз; антиоксидантная система. 